\title{
The reproductive cycle of the oyster Crassostrea gasar
}

\author{
Gomes, CHAM. ${ }^{a *}$, Silva, FC. ${ }^{a}$, Lopes, GR. ${ }^{a}$ and Melo, CMR. ${ }^{a}$ \\ ${ }^{a}$ Laboratório de Moluscos Marinhos, Universidade Federal de Santa Catarina - UFSC, Rua dos Coroas, \\ 503, Barra da Lagoa, CEP 88061-600, Florianópolis, SC, Brazil \\ *e-mail: chlabmol@cca.ufsc.br
}

Received: April 4, 2013 - Accepted: June 27, 2013 - Distributed: December 31, 2014

(With 7 figures)

\begin{abstract}
The purpose of this study was to analyze the reproductive cycle of the oyster Crassostrea gasar (= C. brasiliana) in the field and the laboratory. The reproductive cycle of the animals was evaluated in the field at Sambaqui Beach, Florianópolis, SC (27 29'18” S and 48 32'12” W) from May 2008 through November 2009. In July, the animals were in the resting stage. The early growth stage began in August and was followed by the late growth stage in October. In November and December, the oysters began to enter the mature stage. Females in spawning condition were predominant during these months. The stages of the reproductive cycle were positively associated with temperature $(\mathrm{r}=0.77, \mathrm{P}<0.01)$ and negatively associated with salinity $(\mathrm{r}=0.56, \mathrm{P}=0.042)$. These findings demonstrated that increased temperature and reduced salinity influence the reproductive development of Crassostrea gasar. The condition index (CI) of the animals was also associated with the seawater temperature. The highest values of the condition index were observed during the months when the temperature of the seawater was gradually increasing. A laboratory experiment was performed to test the effect of salinity on the reproductive cycle of the oysters. The experiment was conducted in standardized tanks. The animals were conditioned using two salinities (24\% and 34\%o). The salinity regime influenced the development of the gonadal tissue of the oysters. A salinity of $24 \%$ o produced greater reproductive development.
\end{abstract}

Keywords: oysters, reproductive cycle, Crassostrea gasar, conditioning.

\section{Ciclo reprodutivo da ostra Crassostrea gasar}

\section{Resumo}

O presente estudo teve como objetivo avaliar o ciclo reprodutivo da ostra Crassostrea gasar, em campo e em laboratório. O estádio de desenvolvimento do ciclo reprodutivo dos animais foi acompanhado na Praia do Sambaqui/Florianópolis/ SC (27²9'18'S e 48³2'12'W) entre maio de 2008 e novembro de 2009 . No mês de julho os animais encontravamse no estádio de repouso e entre os meses de agosto a outubro, as ostras seguiram nos estádios de pré-maturação e maturação. Entre os meses de novembro e dezembro, as ostras começaram a ser encontradas no estádio maturo, havendo predominância de fêmeas aptas a eliminação de gametas. Houve associação positiva $(\mathrm{r}=0,77 ; \mathrm{P}<0,01)$ entre o estádio de desenvolvimento do ciclo reprodutivo das ostras e a temperatura, bem como associação negativa com a salinidade $(\mathrm{r}=-0,56 ; \mathrm{P}=0,042)$, demonstrando que tanto o aumento da temperatura como a redução da salinidade são fatores ambientais que influenciam no desenvolvimento reprodutivo das ostras dessa espécie. O índice de condição (IC) dos animais, também teve relação com a temperatura da água do mar, sendo os maiores índices observados nos meses em que a temperatura da água do mar teve aumento gradativo. Também foi realizado um experimento em laboratório visando testar o efeito da salinidade da água sobre o desenvolvimento reprodutivo das ostras. Para tanto, os animais foram condicionados em tanques padronizados e testaram-se duas salinidades (24\%o e 34\%o). Observou-se que o regime de salinidade influenciou o desenvolvimento do tecido gonádico das ostras, sendo que a salinidade de $24 \%$ permitiu aos animais maior desenvolvimento reprodutivo.

Palavras-chave: ostras, ciclo reprodutivo, Crassostrea brasiliana, condicionamento em laboratório.

\section{Introduction}

The development of oyster farming in Brazil has involved three species of the genus Crassostrea: the native oyster Crassostrea rhizophorae (Guilding, 1828), the "mangrove oyster" Crassostrea gasar (Adanson, 1757) and the Pacific oyster Crassostrea gigas (Thunberg,
1793). The culture of the Pacific oyster is well established in the State of Santa Catarina, which contributes to the majority of the cultivated oyster production in the country. However, problems caused by the tropical weather affect the growth of $C$. gigas in other regions of the country. 
In those regions, $C$. gasar $(=C$. brasiliana) is usually used in cropping systems (Christo, 2006). Due to lack of hatcheries to produce seeds in different regions of the Brazil, the cultivation of native oysters depends almost entirely on seeds collected in the natural environment (Pereira et al., 2003). The young oysters collected are then transferred to cropping systems, where they are kept until they reach commercial size. Studies of reproductive cycle, spawning periods and occurrence of larvae to suitable gonad settlement are necessary to ensure the success of seed collection. The information resulting from these studies will allow the correct and timely placement of collectors in each region. A better understanding of the reproductive cycle of the native oyster and its relation to the environment will permit the development of more effective and efficient techniques for the maintenance of the oyster in the laboratory and for its management in the natural environment. Likewise, such understanding can be valuable for identifying the best period for obtaining mature breeders from the natural stocks so that seeds can be produced in the laboratory. The reproductive cycle of the oyster Crassostrea gigas while living in the natural environment has been well described (Mann, 1979; Perdue et al., 1981; Dinamani, 1987; Ruiz et al., 1992; Steele and Mulcahy, 1999; Lango-Reynoso et al., 2000; Li et al., 2000; Chávez-Villalba et al., 2001; Lango-Reynoso et al., 2006; Normand et al., 2008).

The most reliable method for evaluating the development of the reproductive cycle of bivalves is based on histology (Quayle, 1969; Steele and Mulcahy, 1999). Histological methods categorize the reproductive cycle of the oyster according to the characteristics of tissue cells observed at different stages of gonadal development (Gosling, 2003). However, this type of analysis tends to be subjective and should be used in conjunction with quantitative methods. For example, the condition index (CI) (Barber and Blake, 1991; Gosling, 2003) can be used as a quantitative method for the indirect assessment of the reproductive stage of the animal (Quayle and Newkirk, 1989; Rabelo et al., 2005).

The conditioning of bivalves for laboratory breeding can be accomplished by manipulating environmental, physical and nutritional factors during several different seasons (Gallager and Mann, 1986; Utting and Millican, 1997). Several papers have reported that temperature and feeding can affect gonadal development in bivalves (Loosanoff and Davis, 1951; Lannan et al., 1980; Muranaka and Lannan, 1984; Utting, 1993; Utting and Millican, 1997). Loosanoff and Davis (1951) showed that artificial conditions allow the normal development of viable gametes in several species of Crassostrea and thereby allow the production of seed in these oysters, even outside the spawning period.

The native oyster species $C$. gasar is primarily found in regions that are significantly influenced by freshwater inflow from the continent and show large variations in salinity (Siqueira, 2008; Castilho-Westphal, 2012). In the estuaries of Cananéia, the southern coastal region of São Paulo, the distribution of $C$. gasar is strongly influenced by salinity (Pereira et al., 2001). The oyster beds decrease in size as the salinity decreases toward the headwaters (Pereira et al., 2001). The influence of salinity on gametogenesis in C. gigas was verified by Muranaka and Lannan (1984). In C. gasar, a typical estuarine species, conditioning by different salinity regimes may alter the reproductive cycle. Hopkins (1931) described that during exposure to fresh water oysters can remain with the valves closed restricting the animal feedstuff. This fact, affects the amount of energy stored by the animal and take gametogenesis. In a study of Crassostrea virginica (Gmelin, 1791), Butler (1949) reported that salinity affects the physiology and reproductive capacity of animals.

A conditioning technique used in laboratory is to increase the temperature gradually to stimulate gametogenesis. This treatment activates the process responsible for extending the period of gamete production (Muranaka and Lannan, 1984).

In light of these reports, this study aimed to determine, using the reproductive stage and condition index, the seasonal influences on the reproductive cycle of the oyster C. gasar in the natural environment and to evaluate the effects of water salinity on then gonadal development of this species.

\section{Material and Methods}

\subsection{Field experiment}

The experiment was conducted in the North Bay of Santa Catarina Island (27 29' $18^{\circ}$ ' S and 48 32'12' W) from May 2008 through November 2009. The specimens of the oyster Crassostrea gasar $(=C$. brasiliana $)$ used in this study was previously identified to the species level using molecular techniques (Lazoski et al., 2011). Oysters measuring between 43 and $70 \mathrm{~mm}$ in height (Galtsoff, 1964) were stocked in suspended longline lanterns. They were cultured in these lanterns throughout the experimental period. Approximately 20 individuals were sampled at randomly from each lantern. The samples were taken to the laboratory, where biometric data were collected, the condition index [(dry tissue weight/shell weight $) \times 100$ ] was determined and material was obtained for histological analysis. The temperature and salinity were measured at a depth of approximately one meter using a YSI 556 multiparameter probe. During the experimental period, 94 oysters were sampled for analysis. Approximately five individuals from each collection were weighed (total weight). The adductor muscle was sectioned and the soft tissues removed. The meat and the shell were weighed separately to obtain the wet weight. The meat and shell were oven dried at $68^{\circ} \mathrm{C}$ for $48 \mathrm{~h}$. The material was then reweighed to obtain the dry weight (Lawrence and Scott, 1982). The condition index was determined according to Crosby and Gale (1990).

For histological analysis, the soft tissues (15 animals per sample) were placed in Davidson's seawater fixative (Shaw and Battle, 1957) for 48 hours. After fixation, $4 \mathrm{~mm}$ thick sections were made through the labial palps to the region of the rectum. These sections were packaged in cassettes for histological processing and embedded in 
paraffin. Seven micrometer thick sections were cut with a microtome (Normand et al., 2008). The samples were stained using the Harris hematoxylin and eosin procedure. The histological slides obtained were then examined under an optical microscope to determine the gender of the animal and the stage of the reproductive cycle. The stages of the reproductive cycle were determined according to the qualitative rating criteria in Normand et al. (2008).

\subsection{Laboratory Experiment}

The influence of salinity (24 and 34\%o) on the reproductive cycle of the oysters was investigated in the laboratory. The animals were housed in six rectangular 150-1 fiberglass tanks. The oysters were separated by size into two groups. A total of 24 individuals from the first group $(52.07 \pm 4.08 \mathrm{~mm})$ and 12 individuals from the second group $(67.05 \pm 4.96 \mathrm{~mm})$ were placed in each tank. A continuous water flow of $500 \mathrm{ml} / \mathrm{min}$ with moderate aeration was used. The animals were fed a diet containing approximately $16 \times 10^{4}$ cells $/ \mathrm{ml}$ of the microalgal species Chaetoceros muelleri (Lemmerman, 1898). During the experiment, the average water temperature of the tanks was $24 \pm 0.8^{\circ} \mathrm{C}$.

The tanks were cleaned daily by siphoning approximately $10 \%$ of the total volume of water to remove feces and pseudofeces from the bottom. Two 6,000-1 tanks were used at each salinity as water and feeding reservoirs. A $1 / 2 \mathrm{hp}$ pump was used to recirculate the contents of the reservoir and to provide water with food to the experimental tanks.

Water and food were supplied twice a day. In the $24 \%$ salinity treatment, seawater was filtered by using filters that retained $5 \mathrm{~mm}$ particles. The filtered seawater was then mixed with fresh water to keep the salinity between 23-25\%o. In the second treatment (salinity 34\%o), the seawater was also filtered using the procedure described above, but the seawater was not mixed with fresh water and the salinity remained between 33-34\%o. Microalgae were added later to the tanks in a volume necessary to obtain the desired concentration ( $16 \times 104$ cells $/ \mathrm{ml})$.

The maturity of the animals was determined monthly by taking five samples of eight individuals per size class at random from each replicate tank. The samples were collected from May 7 through July 31, 2008. The histological analysis was conducted as previously described for the field experiment.

\subsection{Statistical analysis}

In the field experiment, the gonadal states of the oysters were compared using t-tests with a permutation procedure at a $5 \%$ significance level. We estimated the simple linear correlations between the average gonadal state and salinity and between the gonadal state and the seawater temperature. The developmental changes in the gonadal state were examined using analysis of variance, and the means were compared using the Tukey test.

The laboratory data on the gonadal state of the oysters did not satisfy the assumptions needed to perform parametric statistical tests. Accordingly, the statistical comparisons were made using t-tests with permutation. All tests were performed using the software package SAS ${ }^{\circledR}$ (2003).

\section{Results}

\subsection{Field experiment}

The seawater temperature ranged from 16.1 to $26.6^{\circ} \mathrm{C}$. The same pattern of winter and spring temperatures was found in both years of study. The lowest temperatures occurred from June through August, averaging $19.1 \pm 0.67^{\circ} \mathrm{C}$ in 2008 and $17.68 \pm 0.94^{\circ} \mathrm{C}$ in 2009 . The temperatures in September were variable but had the same minimum values. The temperature began to increase in October and reached its maximum, $26.61^{\circ} \mathrm{C}$, in March 2009 (Figure 1).

The average salinity was $32.4 \pm 2.11 \%$. The minimum salinity, 21.7\%o, was observed in November 2008 after a period of very high precipitation. The maximum salinity, 34.1\%o, occurred in February (Figure 2).

The histological analysis showed that the oysters were in the resting stage (stage 0) during June, July and August. Statistical differences $(\mathrm{P}<0.05)$ were found only in July, when $100 \%$ of the oysters were in this stage in 2008 and $96.77 \%$ in 2009. In August, the oysters were in the early growth stage (1). The reproductive stages during these months differed significantly from those found in subsequent months. A significant increase in the fraction of oysters in the early growth stage (87.5\%) was observed in September. In October, some oysters were in the late growth stage (2).

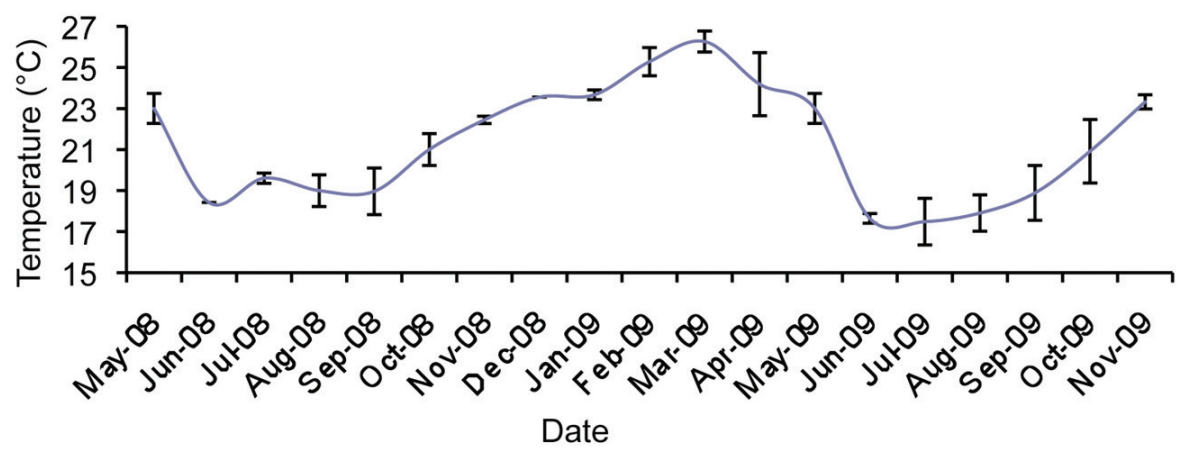

Figure 1. Average seawater temperature during the sampling period. 
Oysters in various stages of gonadal tissue development were found in November, with individuals in the mature stage (3). The first individuals in the spawning stage (4) were observed in early 2009 (Figure 3).

The gonadal state of the animals differed significantly between August and September 2009. In August, approximately $40 \%$ of all individuals were at the early growth stage. However, the gonadal states of oysters in September and in October did not differ significantly. The first individuals in the late growth stage were found in October.

The proportion of the animals in the late growth stage in November differed $(\mathrm{P}<0.05)$ from that found in all other months. The first individuals in the mature stage were found during this period, and the animals began to show signs of spawning. The greatest proportions of mature oysters were observed during December, January and March. Clutches were present from November through April, with a peak in November and another peak in April. From December through February, there were no oysters in the resting stage. Oysters in the resting stage were found in increasing numbers beginning in March (14.28\%).

Figures 4 and 5 show tissue cross sections of the native oyster Crassostrea gasar in different stages of gonadal development.

The gonadal stage of the oysters was positively associated $(\mathrm{r}=0.77, \mathrm{P}<0.01)$ with the temperature and was negatively associated $(\mathrm{r}=-0.56, \mathrm{P}=0.042)$ with the salinity of the seawater. The condition index (CI) of the animals was related to the temperature of the seawater. The highest CI values were observed during the months of higher seawater temperatures. The July temperature averaged $13.0(\mathrm{SD} \pm 2.14)$ in 2008 and $11.3(\mathrm{SD} \pm 2.21)$ in 2009 , when almost all of the oysters were in the resting stage (Figure 6). The CI values increased during the stages of gametogenesis and at the time when the mature stage first appeared (November). The highest CI values were observed in November. The mean values were $15.42(\mathrm{SD} \pm 2.3)$ and 16.40 ( $\mathrm{SD} \pm 3.4$ ), respectively, in 2008 and 2009. The CI decreased beginning in January, after spawning in November and December (Figure 7). It reached its lowest values in April, the final period of the breeding season, when most of the oysters were spawning or reabsorbing the remaining gametes. The difference between the average CI values for January through June and for October through December was statistically significant.

\subsection{Laboratory experiment}

The temperature and salinity were held constant in each treatment during the 78-day experimental period. An initial mortality of $12 \%$ occurred because the oysters were slow to close their valves when they were stimulated as their tanks were being cleaned. All of these animals (12\%) were found to be infested with flatworms. At the beginning of the experiment, the oysters were at the resting or early growth stages. After 15 days of conditioning, $75 \%$ of the

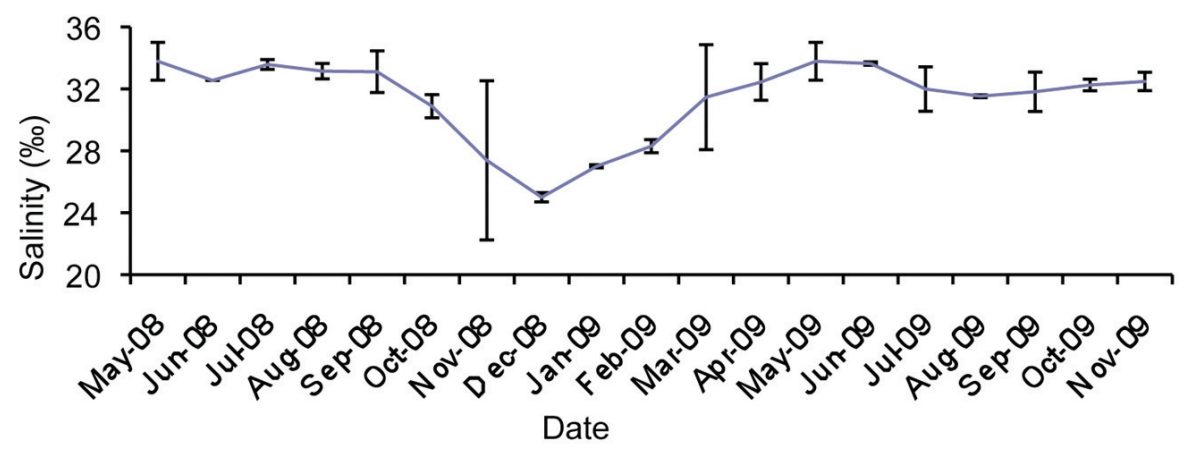

Figure 2. Average seawater salinity during the sampling period.

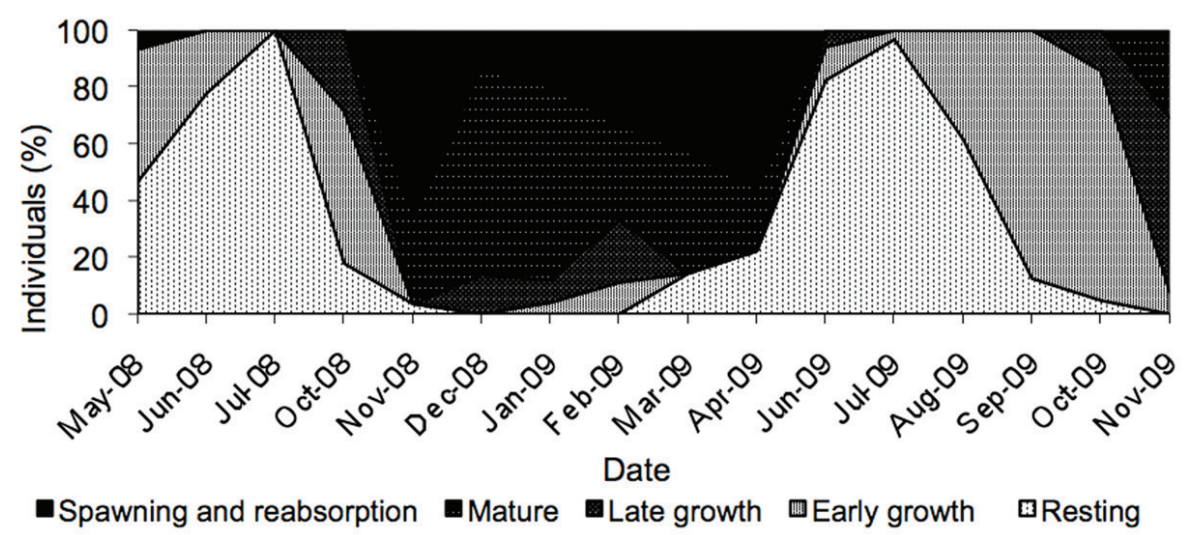

Figure 3. Distribution of gonadal maturation stages over the sampling period. 

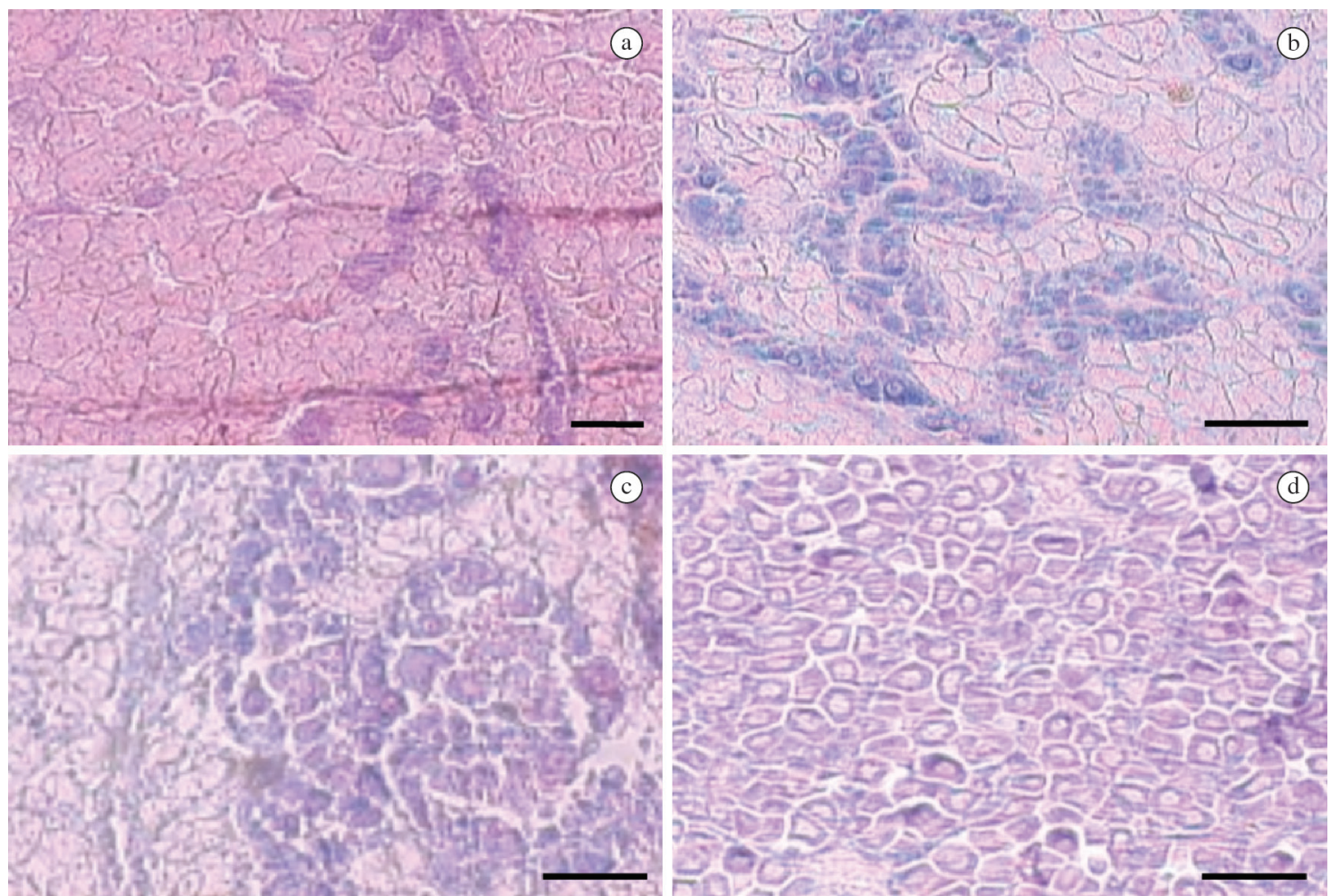

Figure 4. Photomicrographs of tissue cross sections of female Crassostrea gasar at different. stages of the reproductive cycle: (a) resting, (b) early growth, (c) late growth, (d) mature. The bar represents $100 \mu$.
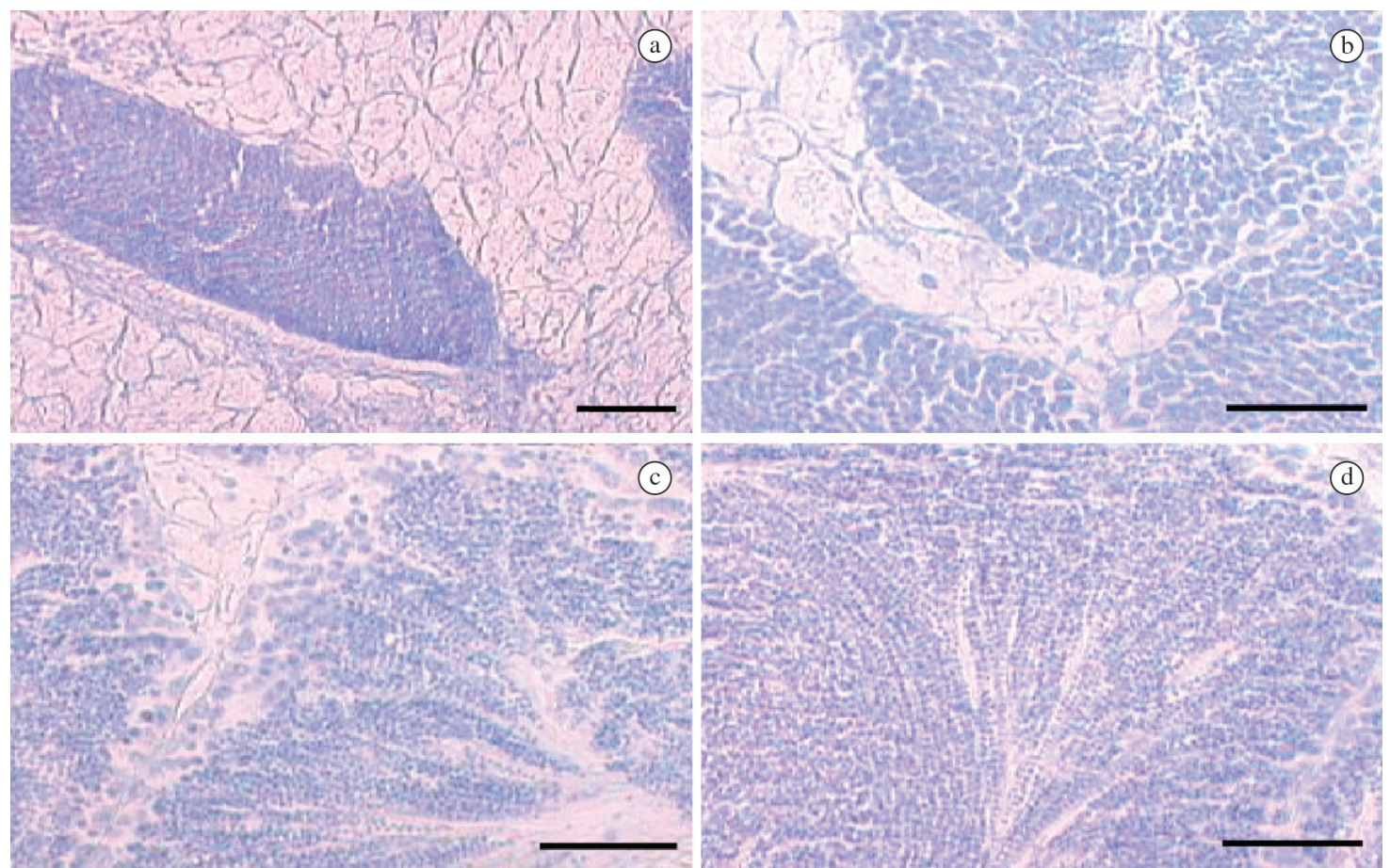

Figure 5. Photomicrographs of tissue cross sections of male Crassostrea gasar at different stages of the reproductive cycle: (a) resting, (b) early growth, (c) late growth, (d) mature. The bar represents $50 \mu$. 


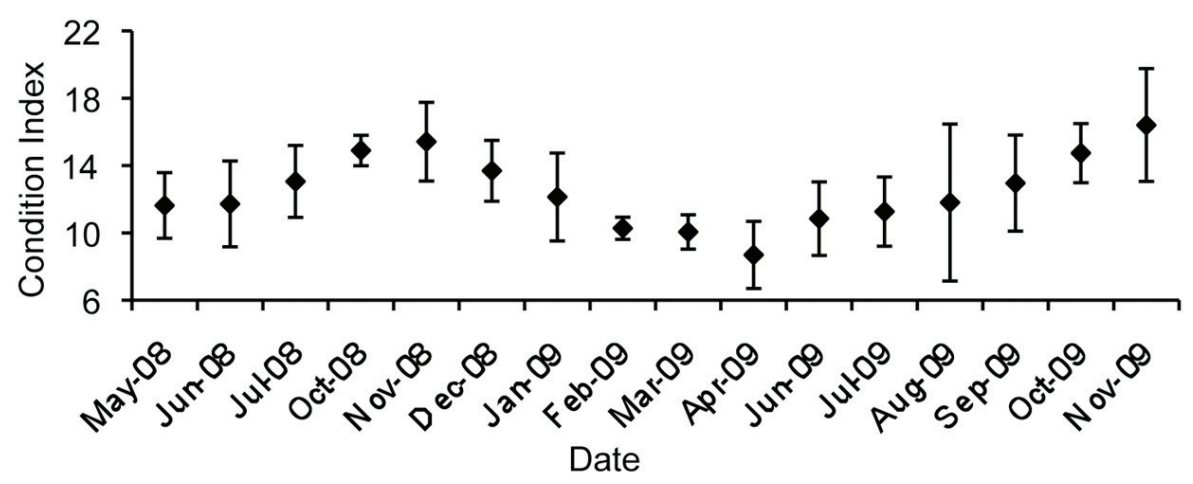

Figure 6. Average condition index of oysters during the sampling period.

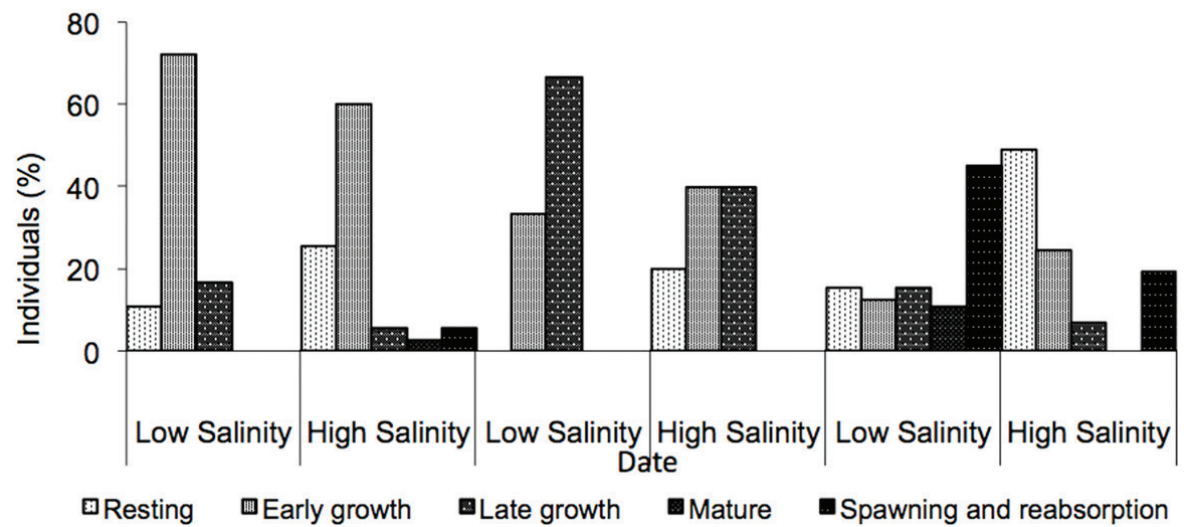

Figure 7. Observed proportions of animals in different gonadal categories (laboratory).

oysters were in the early growth stage. The distribution of the reproductive stages did not differ significantly between treatments $(\mathrm{P}>0.05)$. In June, most oysters in the lowsalinity treatment were at the late growth stage (66.67\%), whereas the animals in the high-salinity treatment were well distributed among the resting stage (20\%), the early growth stage (40\%) and the late growth stage (40\%). In July, the distribution of the gonadal stages differed significantly between treatments. During July, $45.31 \%$ of the oysters in the low-salinity treatment were at the stage of spawning and resorption. In the high-salinity treatment, only $19.3 \%$ of the animals were in the spawning and resorption stages, whereas $49.12 \%$ of the animals were at the resting stage (Figure 7). Throughout the study period, the distribution of the reproductive stages did not differ between the size classes.

\section{Discussion}

\subsection{Field experiment}

The reproductive development of oysters is affected by the seasons and, therefore, by increases in seawater temperature. This information is consistent with previous findings that the periods of gametogenesis of the same species may vary among geographical areas (Lannan et al., 1980). Studies performed in different localities showed that the time required for gametogenesis and for the maturation of the sexual cells increases with latitude (Mann, 1979). A study of C. gigas in Israel (Shpigel, 1989) found that the period of gametogenesis was approximately 50 to 60 days and that the initial age of maturation was 4 to 6 months. Gametogenesis occurred over a shorter period than that found in colder regions, and maturation occurred at an earlier age. In the current study, the gametogenesis period for the native oyster was longer and more well defined than the period of gametogenesis found by Nascimento (1978) for the mangrove oyster species $C$. rhizophorae in the Jacuruna River estuary, Bahia (latitude 13º). Galvão et al. (2000) studied the native oyster $C$. gasar in the Cananéia region of São Paulo state. Between August and November 1998, they found oysters in all stages of gonadal development. In August, the majority of individuals were in the early growth stage. The oysters collected in the current study exhibited well-defined dates for the developmental stages of gonadal tissue. In July of 2008 and 2009, the lowest average temperatures were recorded, and almost all of the animals were in the resting stage. In August, less than half the oysters collected were found to be at the early growth stage. In September 2009, most of the oysters were in this stage. However, Nascimento and Lunetta (1978) found that these stages are extremely rare in native oyster populations in the Northeast of Brazil. Partial spawns, followed by a 
recovery phase, are more frequent throughout the year. Lenz and Boehs (2011) studied the reproductive biology of $C$. rhizophorae in two environments in the Bay of Camamu (BA) and found that these oysters were in different stages of the reproductive cycle throughout the year. It is likely that the reproductive cycle of oysters in these regions is less subject to seasonal influences than it would be in the South and Southeast, where the oysters would be more susceptible to other environmental events, such as rainfall. The results of the current study suggest that in Santa Catarina, C. gasar has the characteristics of the molluscs of temperate regions, where the resting period is well defined and corresponds to the seasons of the year with lower temperatures.

The results of the histological analysis demonstrated that oyster gametogenesis is more intense during the spring, when several stages of gonadal development are present. The observations of temperature and histological data showed that oysters at the early growth stage were first found during the months when the temperature of seawater was near $18^{\circ} \mathrm{C}$. Animals in the late growth stage began to appear during October, when the average temperature rose above $20^{\circ} \mathrm{C}$. As the temperature continued to rise from November through April, oysters reached the mature and spawning stages. These events occurred at the beginning and the end of this period, respectively. In the Paranaguá region, reports based on the recruitment of oysters show that spawning occurs from September to April, with peaks in December and April (Absher, 1989). However, Pereira et al. (1991) concluded that the spawning of the species in Cananéia, a region near the Bay of Paranaguá, occurs extensively from November through May and intermittently during the rest of the year. The sex ratio varied throughout the study period, and individuals of indeterminate sex were present in the winter and early spring. Christo (2006) found a balanced sex ratio in the oysters collected for study, whereas Galvão et al. (2000) observed a predominance of males. The salinity at one of the sampling sites in the Galvão et al (2000) study, was higher than that found at the other sampling points. This difference in salinity and the predominance of female oysters may have influenced the sex ratio. The incidence of hermaphrodites in populations of Crassostrea is low, as found in this study. The incidence of hermaphrodites in a population of C. brasiliana was $0.6 \%$ (Galvão et al., 2000). Comparable results were reported by Nascimento (1978) and by Lenz and Boehs (2011), who reported low incidence rates of 0.52 and $0.76 \%$, respectively, for hermaphroditic $C$. rhizophorae.

Shpigel (1989) observed that the males of C. gigas and Ostrea edulis (Linnaeus, 1758) become mature earlier than the females. This difference is a result of the energy required for vitellogenesis. The maturation of sex cells exhibits differences in timing between males and females. These differences occur in relation to the periods of rest and elimination (Nascimento and Lunetta, 1978). Similar results have been found for $C$. virginica (Kennedy and Battle, 1964).
The results of this study show that individuals developed synchronously. Males and females reached maturity at the same time, although they occurred in different proportions. This finding differs from those reported by the studies previously cited. However, we found that males in the late growth stage, when sperm had already formed, appeared prior to females showing primary oocytes with a completed vitellogenesis phase. Galvão et al. (2000) analyzed the distribution of males and females in different reproductive stages from August through November 1998. In August, approximately $70 \%$ of the males were in the early growth stage and the resting stage. Approximately $30 \%$ of the males were in other stages of gonadal development. During the following months, the percentage of animals in the early growth stage decreased and the percentage of animals in the late growth stage and spawning increased.

Different methodologies are used to estimate the condition index (CI). For example, Galvão et al. (2000) estimated the CI by dividing the weight of the dried meat by the total weight of the oyster. This estimate does not consider how much of the biomass of dried meat can occupy the internal volume of the shell. In this study, the highest values of the condition index found in the two years investigated were in November. These results differ from the findings of Christo and Absher (2006) that the lowest values of the CI occurred in November and the highest values in May. These authors also reported that the reproduction of the animals examined in their study was continuous. This finding may explain the difference between the CI values obtained by these authors and the values obtained in the current study for animals having a well-defined resting stage. In this study, the histological analysis showed that the animals were in the resting stage in July and began to show signs of spawning only in November, the month in which we found animals in the late growth stage, in the mature stage and at the beginning of the spawning stage. The animals that had started to spawn exhibited lower values of the CI. Other authors (Nascimento, 1978; Nascimento and Pereira, 1980; Galvão et al., 2000, Christo and Absher, 2006) also found that high CI values coincided with the period of gonad maturity. In April, the values of the CI were lower because the oysters were at the end of the spawning period. Between July and September, the end of spawning was followed by the resting stage and the early growth stage, during which the animals started to accumulate glycogen.

Dridi et al. (2007) found high CI values in C. gigas during the winter. During this period of sexual inactivity, reserves of energy and nutrients are accumulated. These reserves are used mainly in gametogenesis and decrease during spawning. An experimental study of $C$. gigas under winter conditions found high values of the CI. These high values resulted from the absence of spawning (Fabioux et al., 2005).

\subsection{Laboratory experiment}

The animals in the laboratory conditioning experiment soon exhibited differences from the animals studied in the field. After 15 days of conditioning, more than half of the 
oysters sampled were in the early growth stage, whereas the animals observed in the field showed developmental regression, with nearly half of the oysters in the resting stage. Although the difference between the treatments was not significant in June, the oysters in the low-salinity treatment had a higher level of gonadal development. Most of the animals sampled were in the late growth stage. However, only $40 \%$ of the animals were in this stage in the high-salinity treatment. In June, most of the oysters in the field experiment were in the resting stage. At the end of the laboratory experiment, significant differences were found between the treatments. The low-salinity $(24 \%)$ treatment included oysters at various stages of development. In this treatment, $45.31 \%$ were spawning or reabsorbing. In the high- salinity (34\%o), treatment, $19.3 \%$ of the oysters were spawning or reabsorbing and $49.1 \%$ were in the resting stage. Among many factors that interferes with environmental gametogenesis, temperature and feeding play a very important role (Chávez-Villalba et al., 2001, 2002a, b, 2003).

The experiment began at a time of the year when the lower values of the condition index indicated that the oysters had little or no reserve material. However, the laboratory conditions allowed the reproductive development of males and females and the production of gametes. According to Gallager and Mann (1986), the disruption of the natural reproductive cycle in the laboratory through conditioning by increased temperatures can force gametes to develop prior to the occurrence of other important developmental events. One important milestone is the mobilization of the reserve glycogen that is usually used by shellfish in the synthesis of lipids during vitellogenesis. Because of these factors, the period during which the conditioning is performed influences gamete quality, viability and larval survival (Lannan et al., 1980). The stimulation of gametogenesis and the maturation of the breeding stock of native species taken from the field is the approach used by laboratories for the production of shellfish seed during the winter and early spring, the time at which the mollusk has accumulated its reserves. This observation illustrates the importance of determining the ideal time to collect breeding stock of native species from the natural environment. It further demonstrates the importance of the development of different conditioning techniques that will allow the native breeding stock to produce gametes that will enable the development of larvae that can produce seed oysters for oyster farming.

\section{Conclusions}

The development of the reproductive cycle of native oysters, C. gasar, is positively influenced by increased seawater temperature and decreased salinity. The conditioning of breeding in the laboratory proves to be a viable alternative for obtaining gametes outside the time period in which gamete production normally occurs in the natural environment. However, further studies are needed to verify the viability of such gametes to produce larvae that are able to produce seed oysters.

\section{Acknowledgements}

We thank CT-HIDRO/CT-AGRO/MCT/SEAP-PR/FINEP and $\mathrm{CNPq}$ for financial support.

\section{References}

ABSHER, TM., 1989. Populações naturais de ostras do gênero Crassostrea do litoral do Paraná-Desenvolvimento larval, recrutamento e crescimento. São Paulo: Universidade de São Paulo. 185 p. Tese de Doutorado.

BARBER, BJ. and BLAKE, NJ., 1991. Reproductive physiology. In SHUMWAY, SE. (Ed.). Scallops: Biology, Ecology and Aquaculture. Elsevier: Amsterdam. p. 378-428.

BUTLER, PA., 1949. Gametogenesis in the oyster under conditions of depressed salinity. The Biological Bulletin, vol. 96, no. 3, p. 263-269. http://dx.doi.org/10.2307/1538361. PMid:18153114

CASTILHO-WESTPHAL, GG., 2012. Ecologia da ostra do mangue Crassostrea brasiliana (Lamarck, 1819) em manguezais da Baía de Guaratuba-PR. Paraná: Universidade Federal do Paraná. 118 p. Tese de Doutorado em Ciências Biológicas.

CHÁVEZ-VILLALBA, J., BARRET, J., MINGANT, C., COCHARD, JC. and LE PENNEC, M., 2002a. Autumn conditioning of the oyster Crassostrea gigas: a new approach. Aquaculture, vol. 210, no. 1-4, p. 171-186. http://dx.doi.org/10.1016/S0044-8486(02)00059-5.

CHÁVEZ-VILLALBA, J., POMMIER, J., ANDRIAMISEZA, J., POUVREAU, S., BARRET, J., COCHARD, JC. and LE PENNEC, M., 2002b. Broodstock conditioning of the oyster Crassostrea gigas: origin and temperature effect. Aquaculture, vol. 214, no. 1-4, p. 115-130. http://dx.doi.org/10.1016/S0044-8486(01)00898-5.

CHÁVEZ-VILLALBA, J., BARRET, J., MINGANT, C., COCHARD, JC. and LE PENNEC, M., 2003. Influence of timing of broodstock collection on conditioning, oocyte production, and larval rearing of the oyster Crassostrea gigas (Thunberg) at six production sites in France. Journal of Shellfish Research, vol. 22, no. 2, p. 465-474.

CHÁVEZ-VILLALBA, J., MINGANT, C., COCHARD, JC. and LE PENNEC, M., 2001. Gametogenese chez l'huitre Crassostrea gigas de l'Aber Beno1^t (Bretagne, France), a' la limite nord de son aire de reproduction. Haliotis, vol. 30, p. 1-12.

CHRISTO, SW., 2006. Biologia reprodutiva e ecologia de ostras do gênero Crassostrea Sacco, 1897 na Baía de Guaratuba (Paraná - Brasil): um subsídio ao cultivo. Curitiba: Universidade Federal do Paraná. 145 p. Tese de Doutorado em Zoologia.

CHRISTO, SW. and ABSHER, TM., 2006. Reproductive period of Crassostrea rhizophorae (GUILDING, 1828) and Crassostrea brasiliana (LAMARK, 1819) (Bivalvia: Ostreidae) in Guaratuba Bay, Paraná Brazil. Journal of Coastal Research, vol. 2, no. 39, p. $1215-1218$.

CROSBY, MP. and GALE, LD., 1990. A review and evaluation of bivalve condition index methodologies with a suggested standard method. Journal of Shellfish Research, vol. 9, no. 1, p. 233-237.

DINAMANI, P., 1987. Gametogenic patterns in populations of Pacific oyster, Crassostrea gigas, in Northland, New Zealand. Aquaculture, vol. 64, no. 1, p. 65-76. http://dx.doi.org/10.1016/00448486(87)90206-7. 
DRIDI, S., SALAH ROMDHANE, M. and ELCAFSI, M., 2007. Seasonal variation in weight and biochemical composition of the Pacific oyster, Crassostrea gigas in relation to the gametogenic cycle and environmental conditions of the Bizert lagoon, Tunisia. Aquaculture, vol. 263, no. 1-4, p. 238-248. http://dx.doi.org/10.1016/j. aquaculture.2006.10.028.

FABIOUX, C., HUVET, A., LE SOUCHU, P., LE PENNEC, M. and POUVREAL, S., 2005. Temperature and photoperiod drive Crassostrea gigas reproductive internal clock. Aquaculture, vol. 250 , no. $1-2$, p. 458-470. http://dx.doi.org/10.1016/j. aquaculture.2005.02.038.

GALLAGER, SM. and MANN, R., 1986. Growth and survival of larvae of Mercenaria mercenaria (L.) and Crassostrea virginica (Gmelin) relative to broodstock conditioning and lipid content of eggs. Aquaculture, vol. 56, no. 2, p. 105-121. http://dx.doi. org/10.1016/0044-8486(86)90021-9.

GALTSOFF, PS., 1964. The American oyster Crassostrea virginica. Fish Bulletin, vol. 64, p. 1-480.

GALVÃO, MSN., PEREIRA, OM., MACHADO, IC. and HENRIQUE, MB., 2000. Aspectos reprodutivos da ostra Crassostrea brasiliana de manguezais do estuário de Cananéia, SP $\left(25^{\circ} \mathrm{S}\right.$; $48^{\circ}$ W). Boletim do Instituto de Pesca, vol. 26, no. 2, p. 147-162.

GOSLING, E., 2003. Bivalve molluscs: biology, ecology and culture. Oxford: Fishing News Books. 443 p.

HOPKINS, AE., 1931. Factors influencing the spawning and setting of oysters in Galveston Bay, Texas. Bulletin of the United States Bureau of Fisheries, vol. 47, no. 3, p. 57-83.

KENNEDY, AV. and BATTLE, HI., 1964. Cyclic changes in the gonad of the american oyster, Crassostrea virgínica (GMELIN). Canadian Journal of Zoology, vol. 42, no. 2, p. 305-321. http:// dx.doi.org/10.1139/z64-029.

LANGO-REYNOSO, F., CHÁVEZ-VILLALBA, J., COCHARD, JC. and LE PENNEC, M., 2000. Oocyte size, a means to evaluate the gametogenic development of the Pacific oyster Crassostrea gigas (Thunberg). Aquaculture (Amsterdam, Netherlands), vol. 190, no. 1-2, p. 183-199. http://dx.doi.org/10.1016/S00448486(00)00392-6.

LANGO-REYNOSO, F., CHÁVEZ-VILLALBA, J. and LE PENNEC, M., 2006. Reproductive patterns of the pacific oyster Crassostrea gigas in France. Invertebrate Reproduction \& Development, vol. 49, no. 1-2, p. 41-50. http://dx.doi.org/10.10 80/07924259.2006.9652192.

LANNAN, JE., ROBINSON, AK. and BREESE, WP., 1980. Broodstock management of Crassostrea gigas: II. Broodstock conditioning to maximise larval survival. Aquaculture (Amsterdam, Netherlands), vol. 21, no. 4, p. 337-345. http:// dx.doi.org/10.1016/0044-8486(80)90068-X.

LAWRENCE, DR. and SCOTT, GI., 1982. The Determination and Use of Condition Index of Oysters. Estuaries, vol. 5, no. 1, p. 23-27. http://dx.doi.org/10.2307/1352213.

LAZOSKI, C., GUSMÃO, J., BOUDRY, P. and SOLÉ-CAVA, AM., 2011. Phylogeny and phylogeography of Atlantic oyster species: evolutionary history, limited genetic connectivity and isolation by distance. Marine Ecology Progress Series, vol. 426, p. 197-212. http://dx.doi.org/10.3354/meps09035.

LENZ, T. and BOEHS, G., 2011. Ciclo reproductivo del ostión de manglar Crassostrea rhizophorae (Bivalvia: Ostreidae) en la Bahía de Camamu, Bahia, Brasil. Revista de Biologia Tropical, vol. 59, no. 1, p. 137-149. PMid:21516642.
LOOSANOFF, VL. and DAVIS, HC., 1951. Delaying spawning of lamellibranchs by low temperature. Journal of Marine Research, vol. 10 , p. 1-29.

MANN, R., 1979. Some biochemical and physiological aspects of growth and gametogenesis in Crassostrea gigas and Ostrea edulis grown at sustained elevated temperatures. Journal of the Marine Biological Association of the United Kingdom, vol. 59, no. 01, p. 95-110. http://dx.doi.org/10.1017/S0025315400046208.

MURANAKA, MS. and LANNAN, JE., 1984. Broodstock management of Crassostrea gigas: Environmental influences on broodstock conditioning. Aquaculture, vol. 39, no. 1-4, p. 217-228. http://dx.doi.org/10.1016/0044-8486(84)90267-9.

NASCIMENTO, IA., 1978. Reprodução da ostra do mangue, Crassostrea rhizophorae (GUILDING, 1828). São Paulo: Universidade de São Paulo. 200 p. Tese de Doutorado do Instituto de Biociências.

NASCIMENTO, IA and LUNETTA, J.E., 1978. Ciclo sexual da ostra do mangue e sua importância para o cultivo. Boletim Fisiologia Animal. São Paulo. Universidade de São Paulo, vol. 2, p. 63-98.

NASCIMENTO, IA. and PEREIRA, SA., 1980. Changes on the condition index for mangrove oysters (Crassostrea rhizophorae) from Todos os Santos Bay, Salvador, Brazil. Aquaculture, vol. 20, no. 1, p. 9-15. http://dx.doi.org/10.1016/0044-8486(80)90057-5.

NORMAND, J., LE PENNEC, M. and BOUDRY, P., 2008. Comparative histological study of gametogenesis in diploid and triploid Pacific oysters (Crassostrea gigas) reared in a estuarine farming site in France during the 2003 heatwave. Aquaculture, vol. 282 , no. $1-4$, p. $124-129$. http://dx.doi.org/10.1016/j. aquaculture.2008.06.026.

PERDUE, JA., BEATTIE, JH. and CHEW, KK., 1981. Some relationships between gametogenic cycle and summer mortality phenomenon in the pacific oyster (Crassostrea gigas) in Washington State. Journal of Shellfish Research, vol. 1, no. 1, p. 9-16.

PEREIRA, O.M., MACHADO, I.C., HENRIQUES, M.B., GALVÃO, M S.N. and YAMANAKA, N., 2001. Crescimento da ostra Crassostrea brasiliana semeada sobre tabuleiro em diferentes densidades na região estuarino-lagunar de Cananéia-SP $\left(25^{\circ} \mathrm{S}, 48^{\circ} \mathrm{W}\right)$. Boletim do Instituto de Pesca, Sao Paulo, vol. 27 , no. 2, p. 163-174.

PEREIRA, OM., HENRIQUES, MB. and MACHADO, IC., 2003. Estimativa da curva de crescimento da ostra Crassostrea brasiliana em bosques de mangue e proposta para sua extração ordenada no estuário de cananéia, SP, Brasil. Boletim do Instituto de Pesca, vol. 29, no. 1, p. 19-28.

PEREIRA, O.M., GALVÃO, M S.N. and TANJI, S., 1991. Época e método de seleção de sementes de ostra Crassostrea brasiliana (Lamarck, 1819) no complexo estuarino-lagunar de Cananéia, Estado de São Paulo $\left(25^{\circ} \mathrm{S} ; 48^{\circ} \mathrm{W}\right)$. Boletim do Instituto de Pesca, vol. 18, p. 41-49.

LI, Q., OSADA, M. and MORI, K., 2000. Seasonal biochemical variations in Pacific oyster gonadal tissue during sexual maturation. Fisheries Science, vol. 66, no. 3, p. 502-508. http://dx.doi. $\operatorname{org} / 10.1046 /$ j.1444-2906.2000.00067.x.

QUAYLE, DB., 1969. Pacific Oyster Culture in British Columbia. Ottawa: Fisheries Research Board of Canada. 192 p.. Bulletin 169.

QUAYLE, DB. and NEWKIRK, GF., 1989. Farming Bivalve Molluscs: methods for study and development. Louisiana: The World Aquaculture Society. 294 p. 
RABELO, MF., AMARAL, MCR. and PFEIFFER, MC., 2005. Índice de Condição de ostras Crassostrea rhizophorae (Guilding 1828) de uma baía contaminada por metais pesados. Brazilian Journal of Biology, vol. 65, no. 2, p. 345-351.

RUIZ, C., ABAD, M., SEDANO, F., GARCIA-MARTIN, LO. and SÀNCHEZ LÒPEZ, JL., 1992. Influence of seasonal environmental changes on the gamete production and biochemical composition of Crassostrea gigas (Thunberg) in suspended culture in El Grove, Galicia, Spain. Journal of Experimental Marine Biology and Ecology, vol. 155, no. 2, p. 249-262. http://dx.doi. org/10.1016/0022-0981(92)90066-J.

SAS Institute Inc., 2003. SAS OnlineDoc ${ }^{\circledR}$ 9.1. Cary, NC: SAS Institute Inc.

SHAW, BL. and BATTLE, HI., 1957. The gross and microscopic anatomy of the digestive tract of the oyster Crassostrea virginica (Gmelin). Canadian Journal of Zoology, vol. 35, p. 325-347.

SHPIGEL, M., 1989. Gametogenesis of the European flat oyster (Ostrea edulis) and Pacific oyster (Crassostrea gigas) in warm water in Israel. Aquaculture (Amsterdam, Netherlands), vol. 80, no. 3-4, p. 343-349. http://dx.doi.org/10.1016/0044-8486(89)90181-6.

SIQUEIRA, KLF., 2008. Avaliação do sistema de cultivo de ostra do gênero Crassostrea (SACCO, 1897) no estuário do rio Vaza-Barris (Sergipe). Aracaju: Universidade Tiradentes UNIT. 77 p. Dissertação de Mestrado em Saúde e Ambiente.

STEELE, S. and MULCAHY, MF., 1999. Gametogenesis of the oyster Crassostrea gigas in southern Ireland. Journal of the Marine Biological Association of the United Kingdom, vol. 79, no. 4, p. 673-686. http://dx.doi.org/10.1017/S0025315498000836.

UTTING, SD., 1993. Procedures for the maintenance and hatchery-conditioning of broodstocks. World Aquaculture, vol. 24 , no. 3, p. $78-82$.

UTTING, SD. and MILLICAN, PF., 1997. Techniques for the hatchery conditioning of bivalve broodstocks and the subsequent effect on egg quality and larval viability. Aquaculture (Amsterdam, Netherlands), vol. 155, no. 1-4, p. 45-54. http://dx.doi.org/10.1016/ S0044-8486(97)00108-7. 